\title{
Research
}

\section{Innovation, Cooperation, and the Perceived Benefits and Costs of Sustainable Agriculture Practices}

\author{
Mark Lubell $^{1}$, Vicken Hillis ${ }^{1}$, and Matthew Hoffman ${ }^{1}$
}

\begin{abstract}
A central goal of most sustainable agriculture programs is to encourage growers to adopt practices that jointly provide economic, environmental, and social benefits. Using surveys of outreach professionals and wine grape growers, we quantify the perceived costs and benefits of sustainable viticulture practices recommended by sustainability outreach and certification programs. We argue that the mix of environmental benefits, economic benefits, and economic costs determine whether or not a particular practice involves decisions about innovation or cooperation. Decision making is also affected by the overall level of knowledge regarding different practices, and we show that knowledge gaps are an increasing function of cost and a decreasing function of benefits. How different practices are related to innovation and cooperation has important implications for the design of sustainability outreach programs. Cooperation, innovation, and knowledge gaps are issues that are likely to be relevant for the resilience and sustainability of many different types of social-ecological systems.
\end{abstract}

Key Words: cooperation; innovation; knowledge networks; resilience; sustainability; sustainable agriculture

\section{INTRODUCTION}

The term sustainability has a long history in agricultural research and practice as a concept designed to foster integration among economic, environmental, and social goals (Hansen 1996). The debate over sustainability has also informed the ideas of resilience and linked social-ecological systems in agriculture (Folke et al. 2002, Milestad and Hadatch 2003, Spielman et al. 2011). Ikerd (1990:18) defines sustainable agriculture as "farming systems that are capable of maintaining their productivity and utility indefinitely," and that are "resource-conserving, environmentally compatible, socially supportive, and commercially competitive." To achieve these goals, many agricultural commodities and regions have developed local sustainability programs and partnerships that encourage growers to adopt sustainable practices (Warner 2007a,b). Ideally, sustainable practices provide environmental and social benefits, and at the same time reduce input costs and increase economic returns to growers.

We argue that the balance of economic, environmental, and social costs and benefits varies across different sustainability practices and affects how growers make decisions and how outreach will influence adoption (Pannell 2008). In addition, knowledge gaps about the existence of a sustainable practice, the expected costs and benefits of adoption, and exactly how to implement a practice can serve as major barriers to adoption. These issues have important implications for improving agricultural outreach programs that encourage grower adoption of sustainable practices. We also think these issues are likely to be at hand in most social-ecological systems, although the key variables driving their dynamics may vary according to institutional, social, and ecological contexts (Ostrom 2009).
We explore these ideas using data from surveys of outreach professionals and wine grape growers in California viticulture. Outreach professionals advise growers and landowners about viticulture management, and include cooperative extension advisers, producer group staff, vineyard management consultants, Pest Control Advisers (PCA), and university professors and researchers. Outreach professionals communicate information about agricultural practices directly to growers, and are therefore a crucial component of the knowledge network for sustainable agriculture. According to a study conducted by the California Sustainable Winegrowing Alliance (CSWA), 30\% of wine grape growers indicated PCAs, and 25\% indicated Farm Advisers as their most important source of information (Brodt and Thrupp 2009). We supplement the outreach data with data from the CSWA study and semistructured qualitative interviews of wine grape growers in the Lodi, Napa Valley, and Central Coast wine regions of California. These three regions have been leaders in developing regional sustainability partnerships and thirdparty certifications.

We focus on two main ideas. First, we argue that adoption of sustainable practices features the characteristics of two social processes: innovation (Tornatzky and Klein 1982, Feder and Umali 1993, Wenjert 2002, Rogers 2003, Ghadim et al. 2005) and cooperation (Ostrom 1990, Lubell 2004, Nowak 2006). Innovation is more important for practices in which economic benefits to the grower outweigh the costs of implementation, whereas cooperation is important for practices in which social benefits are a product of the joint efforts of many growers. Our analysis ranks sustainable practices in terms of their economic costs, economic benefits, and environmental benefits. In doing so, we identify which sustainability practices are adopted by growers through the processes of innovation 
or cooperation. We make recommendations about the types of outreach and education programs that will be most effective for encouraging both types of practices.

Second, we argue that the way growers learn and process information tends to preserve knowledge gaps about sustainable practices that are barriers to practice adoption. Knowledge gaps occur when there is a difference between the knowledge stored in the minds of growers and the objective facts about the existence, effectiveness, and implementation of a particular practice. Reducing knowledge gaps is a research priority because they can be significant barriers to practice adoption and the development of sustainable agriculture systems (Reganold et al. 2011). We propose an agricultural knowledge network framework that hypothesizes, because of the learning strategies and networks among viticulture decision makers, knowledge gaps will be more prevalent for practices with high costs and low benefits.

Sustainable viticulture is an excellent system for studying these issues for a number of reasons. In 2009, a total of 531,000 acres of wine grapes were planted in California (USDA $2009 a$ ), and the state's growers grossed about $\$ 2.3$ billion (calculated from USDA 2009b). Concurrent with this important economic activity there is conflict on environmental issues including nonpoint source pollution from pesticides (Epstein and Bassein 2003) and nutrients (Ahearn et al. 2005), water use for frost protection and irrigation (see National Oc eanic and Atmospheric Administration letter), and loss of agricultural land to urban development (Espeljel et al. 1999, Merenlender et al. 2005).

At the same time, sustainability programs in the viticulture sector have developed quickly relative to other commodities (Warner 2007b). The importance of geographic and quality branding in wine marketing (Lapsley 1996) coupled with the recent increase in wine eco-labeling has opened the door to linking the ecological, social, and economic benefits of sustainability practices with consumer preferences (Warner 2007a,b). There are several regional programs in California with a fairly long history; among the most recognized are those associated with the Lodi Winegrape Commission, the Central Coast Vineyard Team, Napa Valley Grape Growers Association, and the California Sustainable Winegrowing Alliance. Most programs began with integrated pest management and evolved to become more systems-oriented 'whole-farm' programs, and most recently have developed third-party sustainability certification programs.

Initial studies suggest that these programs help move the viticulture sector toward sustainability goals including implementation of Integrated Pest Management (Klonsky et al. 1998), abating political tensions at the urban-rural interface, decreasing pesticide use, increasing wine grape prices (Broome and Warner 2008), and encouraging growers to adopt sustainable practices (Shaw et al. 2011). Although the long- term economic, environmental, and social benefits of sustainability programs remain to be seen, increasing grower participation and practice adoption are necessary first steps. How growers make decisions in light of the cost/benefits and existing knowledge about different practices is crucial to understanding the operation and effectiveness of these programs.

\section{THEORETICAL PERSPECTIVES ON VITICULTURE DECISION-MAKING AND LEARNING}

There are two social processes that might affect agricultural decision making, depending on the relative economic and environmental costs and benefits of different agricultural practices. Which social process, i.e., innovation or cooperation, is most important has implications for the design of outreach and education programs. We also propose a knowledge-system model that explains the persistence of knowledge gaps regarding sustainable practices, which are a major barrier to adoption.

\section{Innovation, cooperation, and practice adoption}

Two different social processes affect the adoption of sustainable practices in viticulture and other agricultural commodities. Best known is the "diffusion of innovation" model proposed by Rogers (2003) and applied to hundreds of agricultural decision making studies (Prokopy et al. 2008). Rogers (2003:12) defines an innovation as "an idea, practice, or object that is perceived as new by an individual or other unit of adoption." The practices recommended by sustainability programs can be conceptualized as innovations because they generally promote vineyard management techniques not previously used by a particular grower.

The traditional diffusion model assumes that innovations will directly benefit the individual making the decision, what economists call private benefits. The individual learns about the innovation through a social network or other communication channel, and then adopts the practice if the private benefits outweigh costs. The private benefits assumption made the diffusion model particularly powerful for explaining the adoption of new agricultural technology during the Green Revolution, when farmers worldwide were learning about new production techniques that greatly increased yields (Feder et al. 1985).

However, from the standpoint of sustainability, it is important to consider the public costs and benefits of sustainability practices (Wenjert 2002). Public costs and benefits accrue to other people, not just the individual adopter. Sustainability partnerships encourage growers to adopt practices that provide environmental, economic, and social benefits to their broader communities. Public benefits create collective action problems because growers have incentives to free ride on the efforts of others (Ostrom 1990, Lubell 2004, Lubell and Fulton 2008). If everybody free rides, then the public benefits are not provided leaving everybody worse off than full cooperation. 
Table 1. Classification framework for viticulture practices.

\begin{tabular}{|c|c|c|}
\hline & Negative Net Economic Benefits & Positive Net Economic Benefits \\
\hline $\begin{array}{l}\text { Positive Net } \\
\text { Environmental } \\
\text { Benefits }\end{array}$ & $\begin{array}{c}\text { Cooperation Practices (High-priority) } \\
\text { Use of vegetative filter strips (WS) } \\
\text { Written erosion control plan (WS) } \\
\text { Diversion structures for water flows (WS) } \\
\text { Written company sustainability plan (B) } \\
\text { Pheromones for pest mating disruption (P) } \\
\text { Use of alternative fuels (A) } \\
\text { Use only contact herbicides (W) }\end{array}$ & $\begin{array}{c}\text { Innovation Practices (High-Priority) } \\
\text { Computer disease forecasting models (D) } \\
\text { Visual observations to irrigate (WS) } \\
\text { Spot spraying (P) } \\
\text { Reduced pesticide applications (P) } \\
\text { ET-based methods to irrigate (WS) } \\
\text { Shielded sprayer to minimize drift (W) } \\
\text { Irrigation management for disease (D) } \\
\text { Owl boxes/bird perches (P) } \\
\text { Need-based spraying for weeds (W) } \\
\text { Narrowing width of treated strip (W) } \\
\text { Reduced herbicide applications (W) } \\
\text { Pruning to reduce disease (D) } \\
\text { Written monitoring for pests (P) } \\
\text { Dust reduction with cover crops (P) } \\
\text { Regulated deficit irrigation (WS) } \\
\text { Monitor/record total energy (A) } \\
\text { Cover crops as refuge for beneficials (P) } \\
\text { Soil tests for nutrient content, etc. (WS) } \\
\text { Written monitoring of beneficials (P) } \\
\text { Dust reduction on roads (P) } \\
\text { Management for vine balance (V) } \\
\text { Measure soil moisture to track water (WS) } \\
\text { Measure plant water stress (WS) }\end{array}$ \\
\hline $\begin{array}{l}\text { Negative Net } \\
\text { Environmental } \\
\text { Benefits }\end{array}$ & $\begin{array}{c}\text { Cooperation Practices (Low-priority) } \\
\text { Use of alternative electricity (A) } \\
\text { Use of compost (V) } \\
\text { Not burning disposed vines (V) } \\
\text { Third-party certification (B) } \\
\text { Releasing beneficials (P) } \\
\text { Mapping for soil water-holding capacity (WS) } \\
\text { Remove infected vines (D) } \\
\text { Remove diseases wood/fruit (D) } \\
\text { Monitor/record canopy microclimate (V) } \\
\text { Mechanical weed management (W) } \\
\text { Leaf pulling (D) }\end{array}$ & $\begin{array}{c}\text { Innovation Practices (Low-Priority) } \\
\text { Mechanical viticulture activities (V) } \\
\text { Written succession plan (B) } \\
\text { Written human resource plan (B) }\end{array}$ \\
\hline
\end{tabular}

Note: Pest Management (P), Disease Management (D), Weed Management (W), Water/Soil Management (WS), Vine Management (V), Alternative Energy (A), Business Management (B). Practices are sorted within each table cell in decreasing order of net environmental benefits. For example, computer disease forecasting models are perceived to have the highest net environmental benefit among high-priority innovation practices. This ordering corresponds to the quantitative results in Figure 2.

In this research we use surveys of outreach professionals to characterize 44 different vineyard management practices in terms of their private costs, private economic benefits, and public environmental benefits. The relevant practices were identified with the help of an advisory team of viticulture outreach professionals and growers in our study regions, and divided into the broad categories of pest management, disease management, weed management, water and soil management, vine management, alternative energy, and business management. The practices are representative of those included in California's leading sustainable viticulture workbooks (Ohmart and Matthiasson 2000, Dlott et al. 2006, CCVT 2011).

Table 1 lists the different practices and previews our findings about their relative private economic benefits, public environmental benefits, and economic costs. We classify practices in which private economic benefits outweigh economic costs as innovation practices, whereby decision 
making should follow the diffusion of innovation model. Practices in which economic costs outweigh benefits are cooperation practices, whereby the realization of environmental benefits requires collective action among growers and free riding incentives are strong. Of particular importance for sustainability are high priority practices, which feature substantial environmental benefits. Although high priority innovation practices such as cover crops are likely to be adopted because they benefit growers, high priority cooperation practices such as water runoff and erosion control practices require collective action. Low priority practices, on the other hand, may have costs that outweigh any environmental benefits. How practices are classified in terms of innovation or cooperation has important applied implications for outreach and education, which are discussed in the conclusion.

\section{The challenge of knowledge gaps}

Knowledge gaps occur when there is a difference between the knowledge stored in the minds of growers and other agricultural stakeholders, and objective facts about the existence of the practice, estimates about the costs/benefits of a practice, and procedural knowledge about on-the-ground implementation. To analyze the origins and consequences of knowledge gaps, we propose a knowledge network framework that recognizes how growers are embedded in social relationships with a range of actors including other growers, consultants, Cooperative Extension, producer groups, local nonprofit organizations, and other stakeholders who communicate about agricultural practices and other issues. Although sustainability is mostly focused on implementation of practices by growers, the knowledge and learning about practices is distributed throughout the knowledge network.

At any given time, actors have different levels of knowledge about the existence, performance, and implementation of agricultural practices. Incentives to learn about a practice depend on actors' initial evaluation of costs and benefits. If the initial evaluation of benefits is high, there is incentive to gather more information. Conversely, increasing estimates of initial costs create disincentives to learn about a new practice. These learning incentives will lead to greater levels of knowledge about practices with high benefit-cost ratios and lower levels of knowledge about practices with low benefitcost ratios.

Once an actor decides to put effort into learning about a practice, they select from among a wide range of possible learning strategies. For example, growers may experiment with a practice on their farm or a portion of their farm and observe how the practice affects the economic, environmental, and social goals with which they are concerned. Outreach professionals might conduct scientific field research or consult technical literature to evaluate practices. However, individual learning can be costly if the effects are difficult to observe, can only be learned after many seasons, or risk major economic damage if they fail. Thus, actors rely heavily on a range of different social learning strategies and the nature of social learning in a community can heavily affect the distribution of knowledge and spread of innovations (Henrich 2001). For example, some growers may use a conformist strategy whereby they only adopt a practice after the majority of other growers in their social networks also adopt the practice, or they may use a prestige-bias strategy whereby they adopt the practices of large or successful growers or recognized scientific experts in the system.

The knowledge network framework comes full circle by describing how actors cognitively process the information accessed from the knowledge network. Behavioral economists have demonstrated that decisions are subject to loss aversion and status quo bias (Kahneman et al. 1991). Loss aversion means that decision makers weight the disutility from a cost more heavily than the utility of an equal size benefit; they will typically discount expected benefits and inflate expected costs. In the context of agricultural decisions, the current set of practices constitutes the status quo whereas new practices offer the prospects of different benefits and costs. Loss aversion predicts that people will typically discount potential gains from a new technology while overestimating costs. These biases become even stronger in the face of uncertainty, and lead to a preference for maintaining the status quo set of viticulture practices.

In general, we argue that the feedbacks among knowledge, learning, and information availability will create knowledge gaps throughout the network that may reduce the rate of practice adoption among growers. Our survey targets outreach professionals as key actors in the viticulture knowledge network, and measures knowledge gaps using the frequency of "don't know" answers to questions about specific sustainable viticulture practices. The knowledge network framework predicts that practices with low benefits and high costs will experience the largest knowledge gaps because of low learning incentives combined with loss aversion. Conversely, knowledge gaps will be lower for practices with high benefits and low costs.

\section{METHODS}

We use three sources of data to investigate the costs and benefits of sustainable practices and the role of knowledge gaps. First, we conducted a statewide Internet survey of viticulture outreach professionals that targeted university researchers, Cooperative Extension agents, producer group staff, and vineyard management consultants. The outreach survey collected 120 respondents with an overall response rate of $43 \%$. Table 2 reports the distribution of outreach respondents by geography and job type. The geographic categories are based on the regions identified by the California Association of Winegrape Growers via their affiliated online 
information source (california-vineyards.com/wine-regions/ ). The respondents are concentrated in the primary wine grape growing regions of California, although the Central Coast is slightly underrepresented. The respondents reflect the broad range of professions involved with the viticulture knowledge network, with a concentration of vineyard management consultants with direct on-the-ground management experience. Vineyard management consultants are important boundary spanners because they often work directly with both growers and other types of outreach professionals, and many of them are growers themselves.

Table 2. Number of responses by region and job type.

\begin{tabular}{|c|c|c|c|}
\hline Region & $\begin{array}{l}\text { Number } \\
\text { Responded } \\
\text { (Percent } \\
\text { of total) } \\
\end{array}$ & Job Type & $\begin{array}{c}\text { Number } \\
\text { Responded } \\
\text { (Percent of } \\
\text { total) }\end{array}$ \\
\hline $\begin{array}{l}\text { North Coast } \\
\text { (including } \\
\text { Napa/ } \\
\text { Sonoma) }\end{array}$ & $48(40 \%)$ & $\begin{array}{l}\text { Vineyard Manager/ } \\
\text { Consultant } \\
\text { (including PCAs and } \\
\text { "sustainability" } \\
\text { consultants) }\end{array}$ & $65(54 \%)$ \\
\hline $\begin{array}{l}\text { Sacramento } \\
\text { Valley } \\
\text { (including } \\
\text { Lodi) }\end{array}$ & $24(20 \%)$ & $\begin{array}{l}\text { Viticulture Producer } \\
\text { Group Staff }\end{array}$ & $21(18 \%)$ \\
\hline $\begin{array}{l}\text { San Joaquin } \\
\text { Valley }\end{array}$ & $17(14 \%)$ & Cooperative Extension & $15(13 \%)$ \\
\hline Central Coast & $16(13 \%)$ & University & $12(10 \%)$ \\
\hline Foothills & $5(4 \%)$ & Government & $3(3 \%)$ \\
\hline South Coast & $4(3 \%)$ & Other & $2(2 \%)$ \\
\hline No answer & $6(5 \%)$ & No Answer & $2(2 \%)$ \\
\hline Total & 120 & Total & 120 \\
\hline
\end{tabular}

Second, we accessed data from a 2008 survey of 101 wine grape growers participating in the CSWA Sustainable Winegrowing Program (SWP; Brodt and Thrupp 2009). The SWP survey aimed to understand grower motivations and barriers to practice adoption, perceived impacts of the practices, and perceived effectiveness of the SWP.

Third, we conducted 16 in-person interviews of wine grape growers in Lodi, Napa Valley, and Central Coast winegrowing regions to ask their views about sustainability practices and programs. The semistructured interviews provided more detailed and nuanced data about how growers make decisions and their perceptions of practices; such qualitative ethnographic data provides important background for interpreting quantitative results.

\section{RESULTS: INNOVATION AND COOPERATION PRACTICES}

Outreach survey respondents ranked on 7-point Likert scales the effectiveness of 44 different viticulture management practices in terms of their economic costs, economic benefits, and environmental benefits. ${ }^{[1]}$ Figure 1 reports the average perceived benefits and costs of the different categories of practices. Disease management practices are considered the most economically beneficial, whereas water management and energy practices are considered the most environmentally beneficial. Energy practices are also considered the most economically costly, in particular the high capital costs of developing alternative energy sources like solar. Vineyard management practices are also considered costly, especially using compost and disposal of removed vines without burning. Both economic and environmental benefits are perceived to outweigh costs for disease, water, pest, and weed management practices. However, there is variation within each category that can be seen when analyzing individual practices.

Fig. 1. Mean economic costs, economic benefits, and environmental costs for each category of practice.

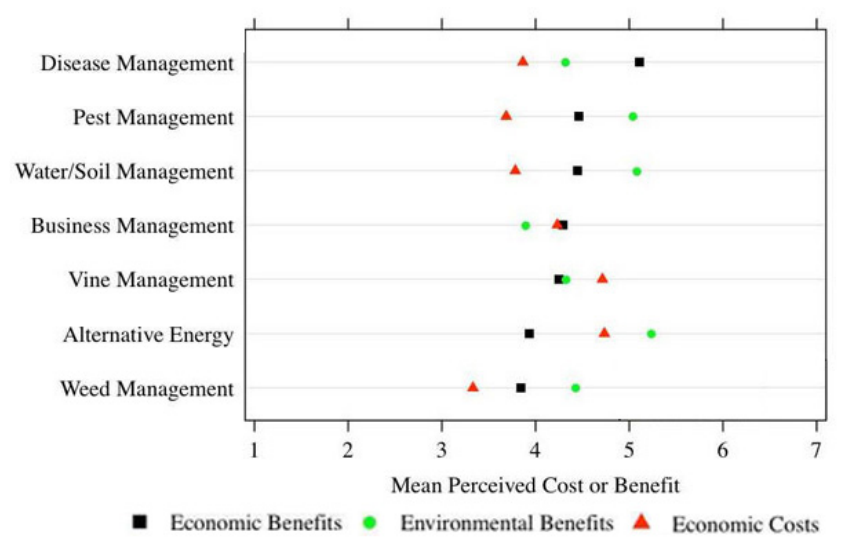

Detailed analysis of individual practices can identify those practices most likely to be influenced by innovation processes, versus those most likely to require cooperation. Figure 2 quantitatively displays the net environmental and economic benefits of the practices shown in Table 1. Net environmental benefits are calculated as average perceived environmental benefits minus average perceived costs for each practice, and net economic benefits are calculated as average perceived economic benefits minus average perceived costs. The majority of practices ( 23 of 44 , or $52 \%$ ) are high priority innovation practices, which are perceived to have positive economic and environmental net benefits. These are some of the classic practices associated with integrated pest management and other earlier outreach and education programs, from which the broader sustainability programs have evolved. It is noteworthy that all of the water management practices classified as innovation are associated with irrigation, and directly affect input costs and vine health. Low priority innovation practices that do not have as many environmental benefits include mechanical methods of viticulture management, but also some of the newer business 
management practices that are not traditionally considered in agricultural management.

Fig. 2. Categorization of practices by net benefits.

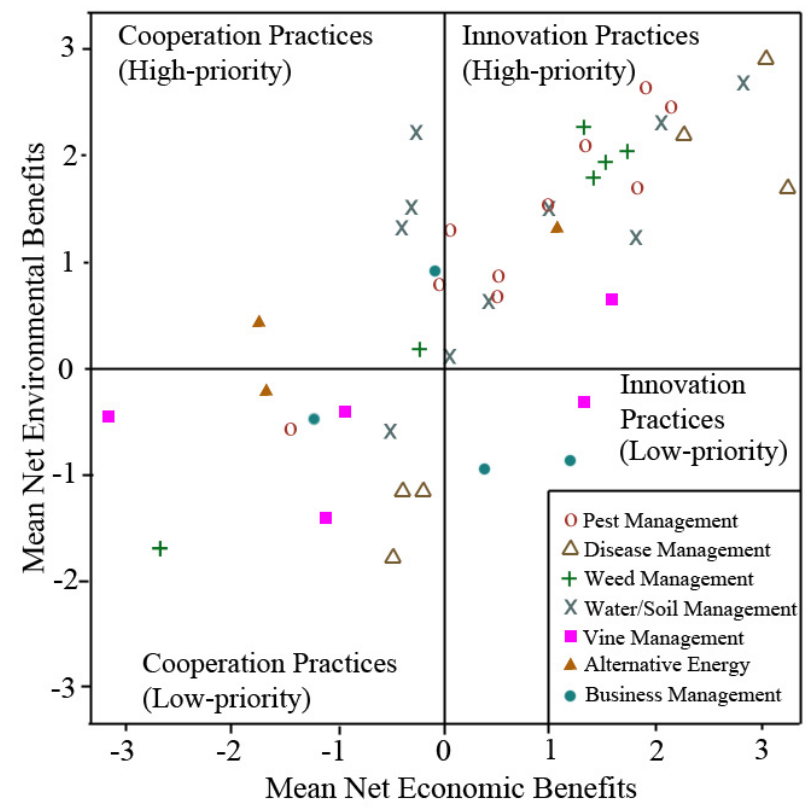

High priority cooperation practices are defined as those for which environmental benefits outweigh economic costs, but also whereby economic costs are higher than economic benefits. Collective action is therefore necessary to realize the environmental benefits. Relative to innovation practices, there are only seven high priority cooperation practices that are perceived to have large enough environmental benefits to justify collective action.

Interestingly, the top three cooperation practices are associated with water management and erosion, which essentially control materials that are moving off the fields and therefore may have little direct return for the vineyard. Although irrigation practices are viewed as an innovation linked to inputs and vine productivity, controlling runoff is a classic negative externality that requires cooperation among growers to solve regional water quality problems. The use of contact/ postemergent herbicides instead of pre-emergent herbicides for weed management is similar to controlling erosion and runoff, because pre-emergent herbicides are potentially harmful to water quality (Tourte et al. 2008). However, there is debate as to whether solely using postemergent herbicides is more costly and less effective for overall weed control.

Alternative fuels and sustainability plans are two relatively new sustainable practices, which are not perceived to have large economic benefits. Switching to alternative fuels often requires substantial capital investment, and sustainability plans add social and environmental issues to basic economic management. Using pheromones to disrupt pest mating is interesting because the economic benefits and costs are perceived as nearly equal; if the economic benefits were slightly higher it would be classified as an innovation practice. However as will be seen later, this practice also has one of the highest levels of knowledge gaps, which reduces our confidences in classifying it as an innovation or cooperation practice. We argue that such knowledge gaps also translate into increased decision making costs in the field.

Low priority cooperation practices form the second largest category, whereby both net environmental and economic benefits are negative. Although these practices might deserve less initial investment, we do not intend the results to be interpreted as justifying removing these practices permanently from consideration. Given that our measure of economic costs is linked to both environmental and economic benefits, it is possible that the aggregate environmental benefits of the low priority cooperation practices would outweigh the portion of the costs that are used to produce those benefits. Furthermore, environmental benefits are difficult to quantify and our outreach respondents report considerable knowledge gaps about these practices. Therefore, all of these categorizations must be considered as a first attempt, with much more research needed on specific quantification of costs and benefits. Such research would also provide a further tool for validation of the subjective estimates presented here.

\section{RESULTS: CONNECTING OUTREACH PERCEPTIONS TO GROWER BEHAVIOR}

Combining data from the outreach survey with the survey of SWP growers allows us to analyze the connection between perceived costs and benefits and grower behavior and attitudes. For 14 of the practices included in the outreach survey, the SWP survey asked growers to identify the reason they adopted the practice, and the perceived impact of the practice. Adoption reasons included environmental concerns and improved production, and impacts included environmental benefits and increased yields. The 14 overlapping practices asked about in both surveys makes it possible to correlate the proportion of growers reporting different adoption reasons and impacts with the average perceived costs and benefits of practices reported by outreach respondents. Figure 3 displays these correlations for economic benefits (first panel) and environmental benefits (second panel).

For example, the outreach survey respondents rated alternative fuels (labeled on Fig. 3) as having the lowest economic benefits, with a mean score of 3.02 on the 1-7 scale. None of the SWP grower survey respondents, i.e., $0 \%$, mentioned adopting alternative fuels to increase yields or perceived improved productivity. Conversely, the outreach respondents 
Fig. 3. Correlation between outreach professional and grower opinions.

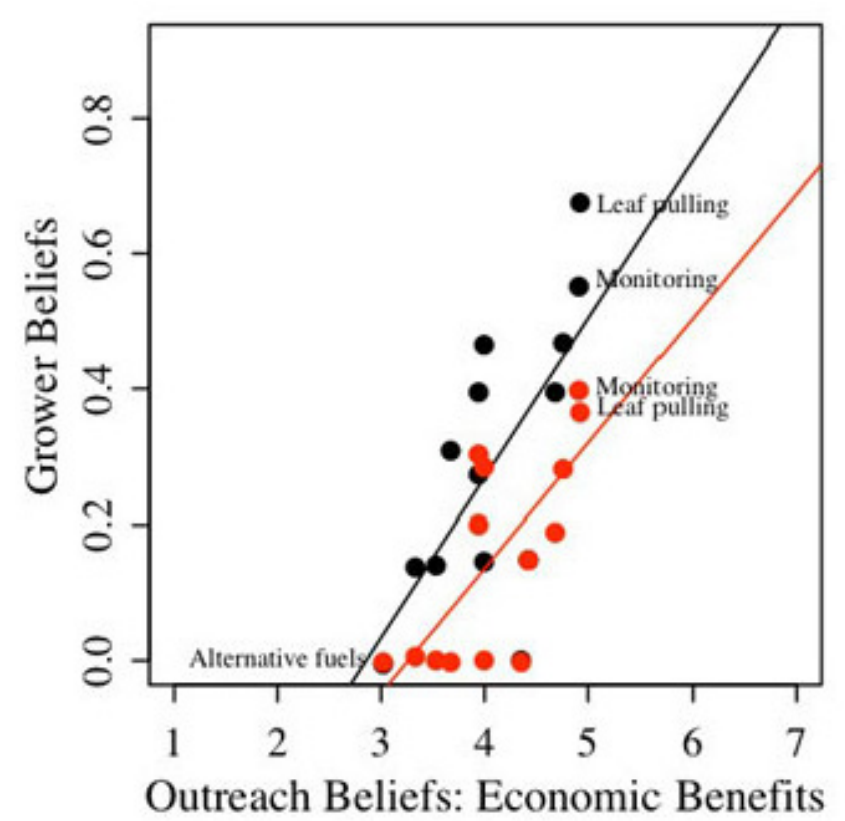

- Adopted to Improve Productivity

- Perceived Increase in Yield

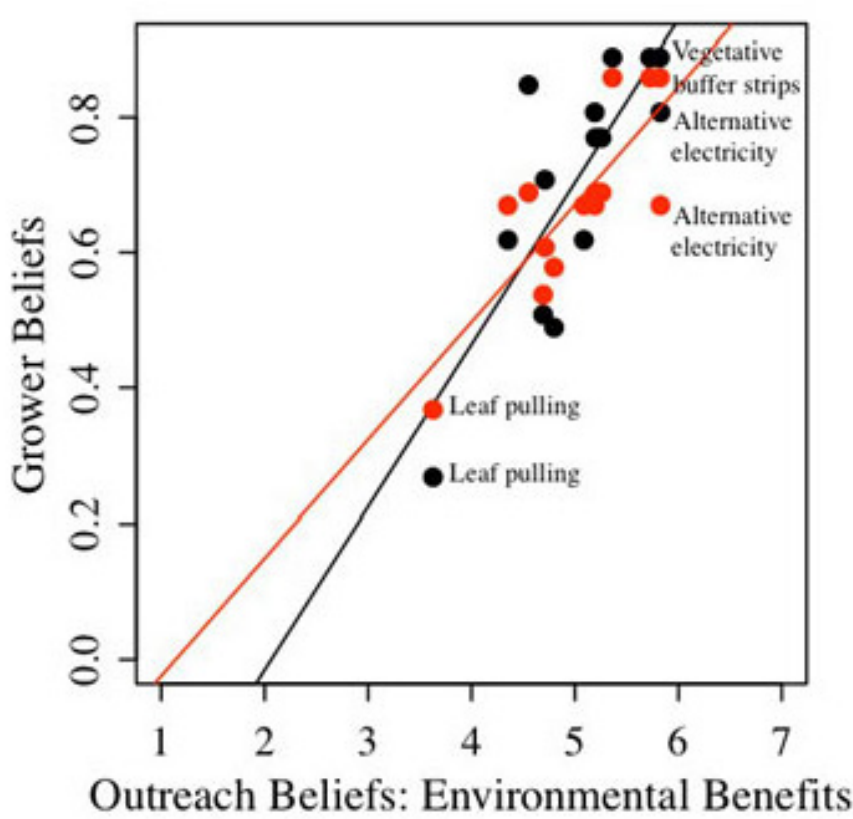

- Adopted for Environmental Reasons

- Perceived Beneficial Environmental Impact rated leaf pulling for disease management and regular monitoring of pests as having the highest economic benefits with mean scores of 4.93 and 4.92, respectively. Leaf pulling and monitoring were mentioned as increasing productivity by $67 \%$ and $56 \%$ of SWP growers, respectively. Concurrently, increased yield was mentioned by $37 \%$ of SWP growers for leaf pulling and $40 \%$ for pest monitoring. Overall, the correlation between average economic benefits perceived by outreach respondents and the proportion of SWP growers who mention adopting the practice to increase yield is 0.69 ( $\mathrm{p}<$ $0.05)$, and $0.68(\mathrm{p}<0.05)$ for the percentage of SWP growers who experience improved productivity. In general, more SWP respondents mentioned these 14 practices providing greater improvements in productivity than improving yields, which suggests these practices may have a larger effect on reducing input costs while providing a similar or slightly improved viticulture output.

A similar story holds for environmental benefits. The outreach respondents rated leaf pulling as having the lowest environmental benefits, with a mean score of 3.63. Only $27 \%$ of the SWP growers mentioned adopting leaf pulling for environmental reasons, and $37 \%$ mentioned observing environmental benefits. On the other hand, the outreach respondents rated alternative electricity and vegetative buffer strips as having the highest environmental benefits with mean scores of 5.83 and 5.82, respectively. Among SWP respondents, $89 \%$ mentioned adopting vegetative buffer strips for environmental reasons and $81 \%$ mentioned adopting alternative electricity for environmental reasons; $86 \%$ observed environmental benefits from vegetative buffer strips and $67 \%$ from alternative electricity. The correlation between the average environmental benefits perceived by outreach respondents and the percentage SWP growers who adopt for environmental reasons is $0.66(\mathrm{p}<0.05)$, and $0.70(\mathrm{p}<0.05)$ for the percentage of SWP growers who experience environmental benefits. Although not reported in the figures, there is also a significant positive correlation $(0.67, \mathrm{p}<0.05)$ between outreach respondents of perceived economic costs and the percentage of SWP growers who mention that the practice increases costs.

The above analyses strongly support the validity of our perceived cost/benefit measures being directly related to grower decision making and perceptions of outcomes. It also highlights the fundamentally economic nature of viticulture management, in which growers are constantly balancing the costs and benefits of different decisions. One of the very 
Fig. 4. Proportion of "don't know” responses for each question and category.

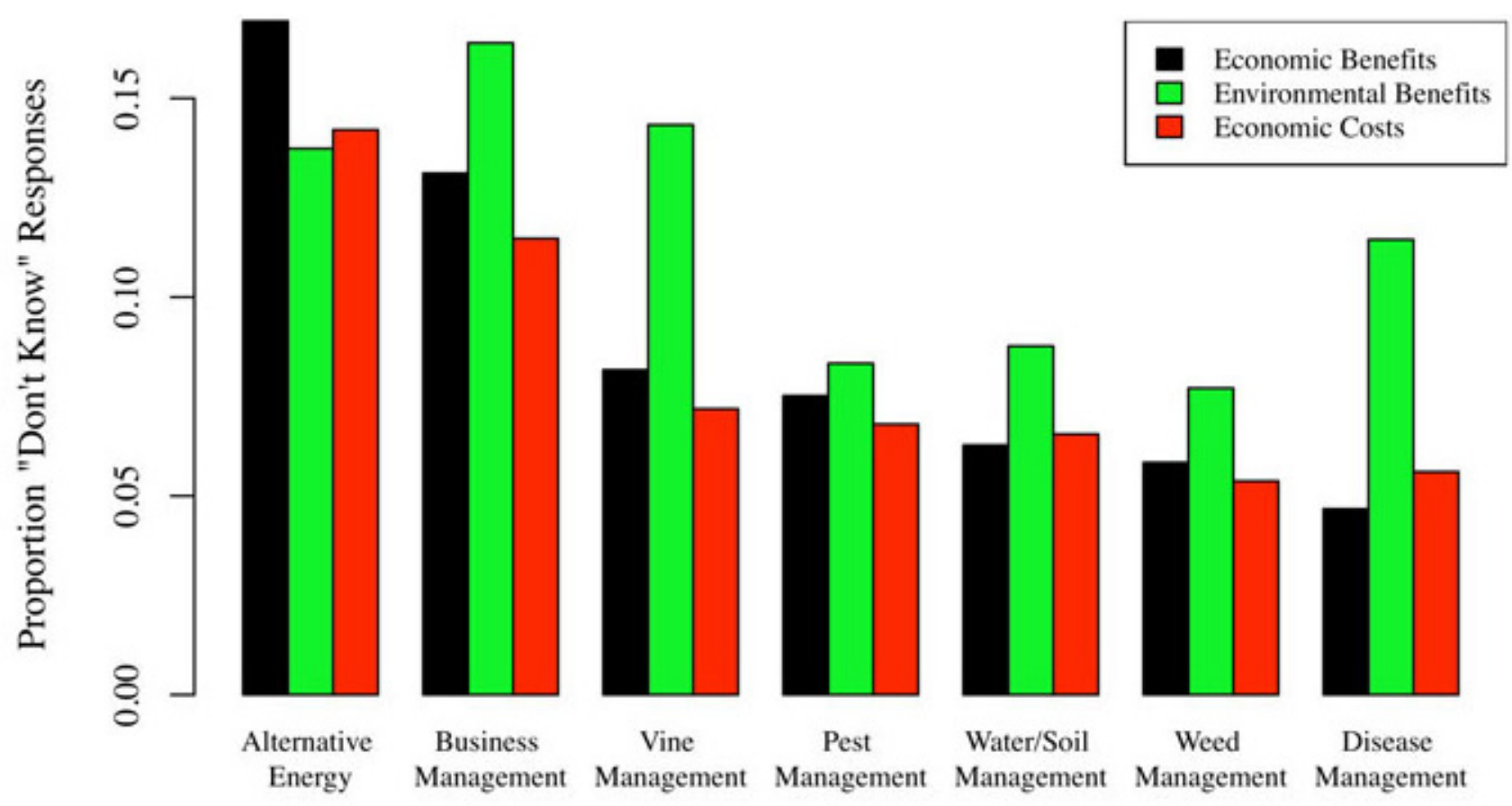

Practice Category

\begin{abstract}
Note: Proportion "Don't know" calculated by summing up all "don't know" responses for each category of practices, and dividing by total number of responses in that category.
\end{abstract}

clearest findings from our interviews is that economics comes first in viticulture management; sustainability is not a relevant concept if the agricultural enterprise goes out of business. The environmental benefits of different practices must be balanced against the overall profitability of the business.

\section{RESULTS: KNOWLEDGE GAPS AND PRACTICE ATTRIBUTES}

Outreach survey respondents were given the option of answering "don't know" when rating the costs/benefits of each practice. The proportion of respondents who answer "don't know" for each practice is one way to measure knowledge gaps. Figure 4 shows the average percentage of "don't know" responses for each category of practice measured on the outreach survey, for environmental benefits, economic benefits, and economic costs. The distribution of knowledge gaps represented has several interesting points. First, the largest knowledge gaps occur for environmental benefits in every case but alternative energy. Second, knowledge gaps appear to be lowest for practices with a long tradition in agriculture such as pest management, whereas newer practices related to alternative energy and business management still have high levels of knowledge gaps. Third, disease and vineyard management are two practices for which the knowledge gaps about environmental benefits are particularly high relative to knowledge about economic factors. Both of these categories are long-standing aspects of viticulture management in terms of focusing on grape quality and vine health, but the environmental implications have only recently been investigated (Robertson and Swinton 2005, Schnepf and Cox 2007).

Figure 5 provides an initial test of some of the hypotheses of the knowledge gap framework by reporting scatterplots with the proportion of "don't know" responses on the vertical axis, and on the horizontal axis the average ratings of economic benefits/costs from among those outreach respondents who did provide an answer for each practice. The knowledge system framework predicts that knowledge gaps should be most prevalent for practices with higher perceived costs, which reduce learning incentives while at the same time risk aversion inflates cost estimates. Knowledge gaps about benefits are expected to be lower as benefits increase, because benefits provide an incentive to engage in learning. Figure 5 is 
Fig. 5. Knowledge gaps as a function of practice benefits and costs.

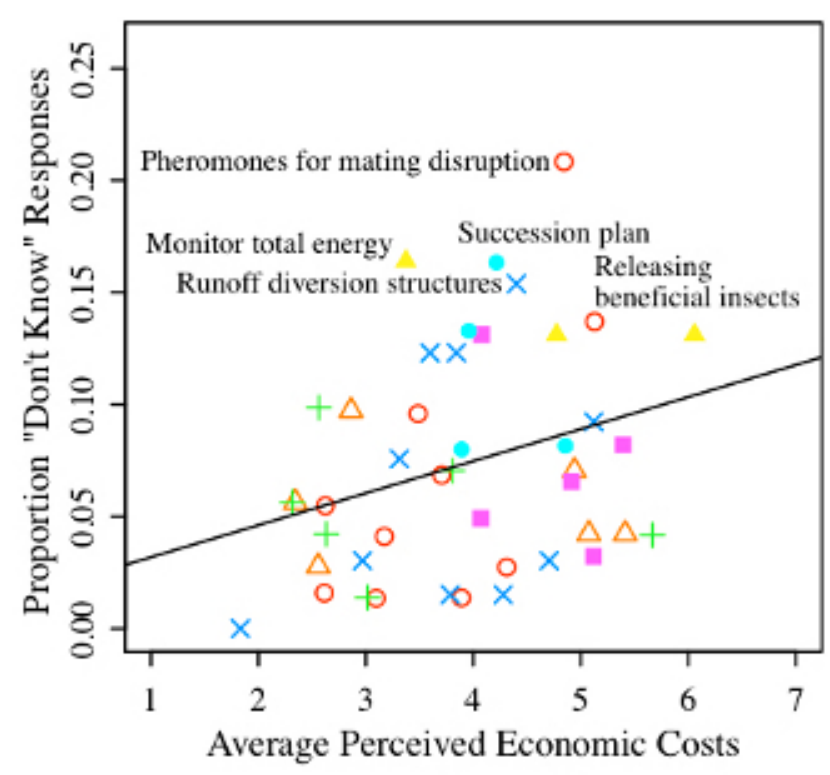

\section{Each point on the graph is a specific practice categorized by type, with the proportion of respondents saying "don't know" on the vertical axis and average benefit/cost evaluations on the horizontal axis.}

\section{Practice Categories}

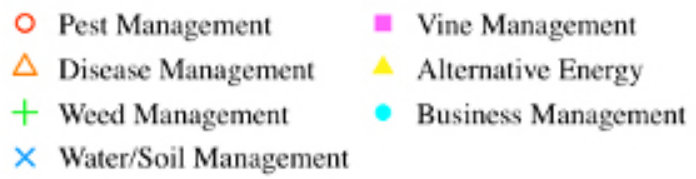

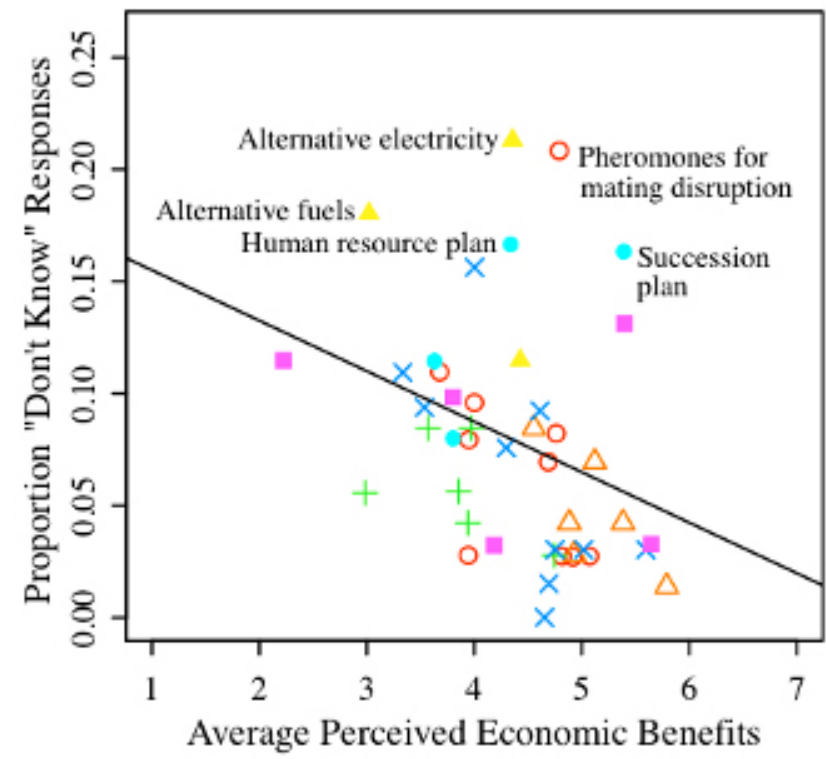

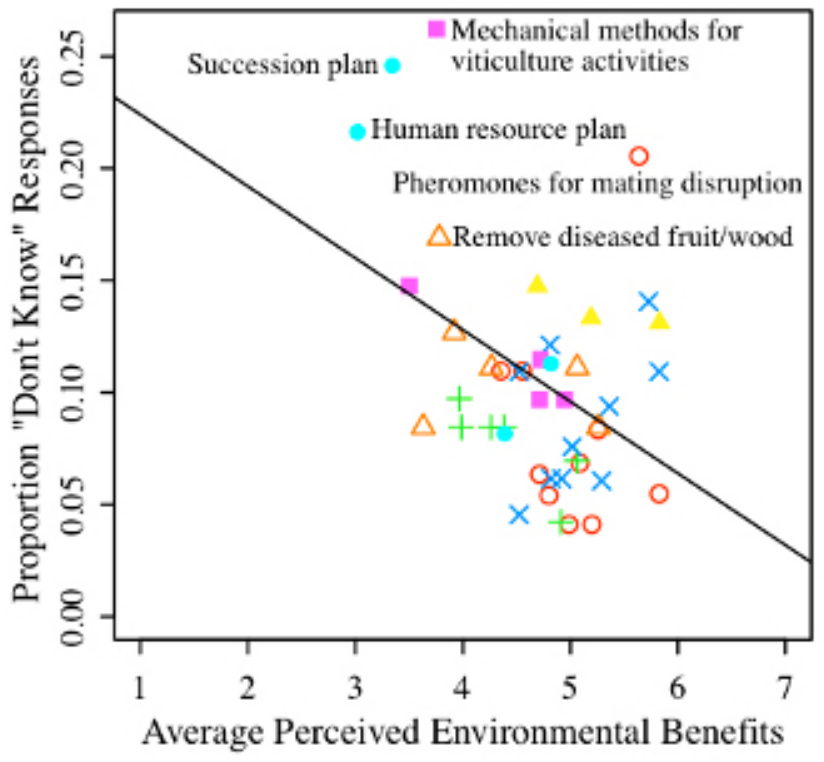

consistent with the expectation of the knowledge gap framework; respondents are less likely to answer "don't know" as benefits increase, but more likely as costs increase. The correlations between the percentage of "don't know" answers and economic costs is $0.30(\mathrm{p}<0.06)$; for economic benefits the correlation is $-0.32(\mathrm{p}<0.05)$; and for environmental benefits the correlation is $-0.42(\mathrm{p}<0.05)$.

Although not shown on the graphs, there are even stronger positive correlations between average economic costs and proportion of "don't know" answers on the private economic benefit questions $(r=0.40 ; \mathrm{p}<0.05)$, and the public benefit questions $(r=0.33, p<0.03)$. This suggests that knowledge gaps about costs create an even greater disincentive to learn about additional benefits of practices. There is also a small positive but insignificant correlation ( $\mathrm{r}=0.12$, not significant) between mean private benefits and proportion of "don't know" answers about environmental benefits. This is intriguing because it is consistent with a learning trade-off whereby actors are learning about private benefits at the expense of learning about environmental benefits. 
Figure 5 also displays the top five practices in terms of "don't know" responses for each type of cost and benefit. These are specific practices that need more research and outreach communication within the knowledge system. Consistent with Figure 4, energy and business management practices such as alternative fuels, alternative energy, human resources planning, and succession planning have the largest knowledge gaps. Pheromone mating disruption also has a large knowledge gap, and this relatively new method of pest control requires additional agroecological research to understand whether innovation or cooperation factors will be the primary drivers of decision making.

Although these initial results are intriguing and consistent with expectations, the hypotheses derived from the knowledge system framework cannot be fully tested using cross-sectional data. The knowledge system framework is really a dynamic and process-based model, in which the elements of the system change over time. Fully testing and exploring the model requires tracking over time how growers and other actors engage learning strategies, how the learning strategies interact with the information environment, how communication flows across knowledge networks, and how information is subsequently processed back into the belief systems of individuals. For example, the research presented here does not directly measure what information growers are exposed to, or what learning strategies they are using. At this point, our main goal for the knowledge system framework is to provide some preliminary evidence that will stimulate further research.

\section{CONCLUSION: IMPLICATIONS FOR} AGRICULTURAL OUTREACH AND EDUCATION

We argue that growers' incentives to adopt sustainable practices depend on the mix of economic costs, economic benefits, and environmental benefits provided by any given practice. The outreach survey identifies innovation practices that are cost-effective for most growers, and cooperation practices that require collective action on the part of growers throughout a community to effectively achieve sustainability goals. The strong correlation between the perceptions of the outreach professionals and the stated decision making considerations of growers corroborates the validity of the measurements. Of course, there is no guarantee that perceived effectiveness will reflect objective economic, environmental, and social outcomes of these practices, which in most cases are still subject to considerable knowledge gaps and require further agroecological and social science research.

Innovation practices are amenable to more traditional outreach methods whereby county extension agents or other experts deliver information about the existence of the practice, technical assistance with implementation, and discussions of the benefits to the growers. Once growers understand these practices are likely to provide private economic benefits in terms of reduced input costs or better agricultural outcomes, they will make the economic decisions to adopt them. However, the outreach community should prioritize those innovation practices with the largest environmental benefits to enhance the overall sustainability of the viticulture industry.

Cooperation practices promise environmental benefits, but only if a substantial number of growers adopt them and free riding incentives are avoided. These practices should be promoted using more community-based and participatory strategies, in which growers come together as an industry group or in multistakeholder partnership. In this case, practices are adopted out of a sense of civic responsibility, social norms of reciprocity, and the desire to create a regional reputation for sustainability. The regional sustainability partnerships discussed in this paper are good examples of this type of efforts. Other examples also exist, such as the Rutherford Dust Society Napa River Restoration Team (www.rutherforddust.o rg/rds/index.cfm), whereby riparian landowners have converted millions of dollars of vineyard land to riparian habitat to help restore the river.

Knowledge gaps pose a substantial barrier to practice adoption. There is less incentive to learn about practices with high economic costs, and loss aversion suggests that people typically inflate costs and discount benefits. Thus it is important to focus research, outreach, and education on some of the practices that we found to have substantial knowledge gaps, such as pheromone mating disruption, alternative energy, and succession planning. Furthermore, our results suggest that knowledge gaps are greatest regarding environmental benefits, in particular for categories of practices such as disease and vineyard management that have long been studied with respect to agricultural productivity. Such research can speed innovation by focusing on how to most efficiently implement practices while maximizing economic returns and environmental benefits.

The issues analyzed here have implications for the broader goals of sustainability, adaptive capacity, and resilience in coupled social-ecological systems (Anderies et al. 2004, Janssen et al. 2006). Questions about innovation, cooperation, and knowledge gaps are likely to be germane for any type of system in which actors must make decisions about different environmental behaviors, in the context of different institutional arrangements. In fact, a potential criticism of the social-ecological system literature is a failure to recognize that cooperation and innovation processes are jointly operating in most systems. However, viticulture is a specific instance of a coupled social-agroecological system, and how these processes play out is likely to vary according to contextual variables, making it important to study these issues in other comparative research systems. Longitudinal research that tracks how behavior, networks, attitudes, institutions, and outcomes change over time in multiple comparative sites 
would be especially valuable to understanding the resilience and sustainability of agricultural systems such as those studied here.

\section{RESPONSES TO THIS ARTICLE}

Responses to this article are invited. If accepted for publication, your response will be hyperlinked to the article. $\underline{\text { To submit a response, follow this link. To read responses }}$ already accepted, follow this link.

\section{ACKNOWLEDGMENTS}

This research is supported by National Science Foundation Grant \#0922567

\section{LITERATURE CITED}

Ahearn, D. S., R. W. Sheibley, R. A. Dahlgren, M. Anderson, J. Johnson, and K. W. Tate. 2005. Land use and land cover influence on water quality in the last free-flowing river draining the western Sierra Nevada, California. Journal of Hydrology 313:234-247. http://dx.doi.org/10.1016/j.jhydrol.2 005.02 .038

Anderies, J. M., M. A. Janssen, and E. Ostrom. 2004. A framework to analyze the robustness of social-ecological systems from an institutional perspective. Ecology and Society 9(1): 18. [online] URL: http://www.ecologyandsociety.org/vol9/ iss $1 / \operatorname{art} 18 /$

Brodt, S., and A. Thrupp. 2009. Understanding adoption and impacts of sustainable practices in California vineyards. California Sustainable Winegrowing Alliance, San Francisco, California, USA. [online] URL: www.sustainablewinegrowing. org/docs/NFWFSurveyReport.pdf

Broome, J. C., and K. D. Warner. 2008. Agro-environmental partnerships facilitate sustainable wine-grape production and assessment. California Agriculture 64(4):133-141. http://dx.d oi.org/10.3733/ca.v062n04p133

Central Coast Vineyard Team (CCVT). 2011. Standards. Central Coast Vineyard Team, Paso Robles, California, USA. [online] URL: http://www.vineyardteam.org/files/sip/SIP\%20 Vineyard\%20Standards\%202011.pdf

Dlott, J., C. Ohmart, J. Garn, K. Birdseye, and K. Ross. 2006. The code of sustainable winegrowing practices workbook. Wine Institute and California Sustainable Winegrape Alliance, San Francisco, California, USA.

Epstein, L., and S. Bassein. 2003. Patterns of pesticide use in California and the implications for strategies for reduction of pesticides. Annual Review of Phytopathology 41:351-375. http://dx.doi.org/10.1146/annurev.phyto.41.052002.095612

Espejel, I., D. W. Fischer, A. Hinojosa, C. García, and C. Leyva. 1999. Land-use planning for the Guadalupe Valley, Baja California, Mexico. Landscape and Urban Planning 45 (4):219-232. http://dx.doi.org/10.1016/S0169-2046(99)00030-4
Feder, G., R. E. Just, and D. Zilberman. 1985. Adoption of agricultural innovations in developing countries: a survey. Economic Development and Cultural Change 33(2):255-298. http://dx.doi.org/10.1086/451461

Feder, G., and D. L. Umali. 1993. The adoption of agricultural innovations: a review. Technological Forecasting and Social Change 43(3-4):215-239. http://dx.doi.org/10.1016/0040-1625 (93)90053-A

Folke, C., S. Carpenter, T. Elmqvist, L. Gunderson, C. S. Holling, and B. Walker. 2002. Resilience and sustainable development: building adaptive capacity in a world of transformations. AMBIO 31(5):437-440.

Ghadim, A. K. A., D. J. Pannell, and M. P. Burton. 2005. Risk, uncertainty, and learning in adoption of a crop innovation. Agricultural Economics 33(1):1-9. http://dx.doi.org/10.1111/ j.1574-0862.2005.00433.x

Hansen, J. W. 1996. Is agricultural sustainability a useful concept? Agricultural Systems 50(2):117-143. http://dx.doi.o rg/10.1016/0308-521X(95)00011-S

Henrich, J. 2001. Cultural transmission and the diffusion of innovations: adoption dynamics indicate that biased culture transmission is the predominate force in behavioral change. American Anthropologist 103(4):992-1013. http://dx.doi.org/ $\underline{10.1525 / \text { aa.2001.103.4.992 }}$

Ikerd, J. E. 1990. Agriculture's search for sustainability and profitability. Journal of Soil and Water Conservation 45 (1):18-23.

Janssen, M. A., Ö Bodin, J. M. Anderies, T. Elmqvist, H. Ernstson, R. R. J. McAllister, P. Olsson, and P. Ryan. 2006. Toward a network perspective of the study of resilience in social-ecological systems. Ecology and Society 11 (1): 15. [online] URL: http://www.ecologyandsociety.org/vol11/iss1/ art15/

Kahneman, D., J. L. Knetsch, and R. H. Thaler. 1991. Anomalies: the endowment effect, loss aversion, and status quo bias. Journal of Economic Perspectives 5(1):193-206.

Klonsky, K., F. Zalom, M. Chandler, C. Ohmart, C. Elmore, and L. Tourte. 1998. The Lodi-Woodbridge Winegrape Commission: a framework for implementing IPM. Integrated Pest Management Reviews 3:243-255. http://dx.doi.org/10.10 23/A:1026471824812

Lapsley, J. 1996. Bottled poetry: Napa winemaking from prohibition to the modern era. University of California Press, Berkeley, California, USA.

Lubell, M. 2004. Collaborative watershed management: a view from the grassroots. Policy Studies Journal 32 (3):341-361. http://dx.doi.org/10.1111/j.1541-0072.2004.00069. $\underline{\mathrm{X}}$ 
Lubell, M., and A. Fulton. 2008. Local policy networks and agricultural watershed management. Journal of Public Administration Research and Theory 18(4):673-696. http://dx .doi.org/10.1093/jopart/mum031

Merenlender, A. M., C. Brooks, D. Shabazian, S. Gao, and R. Johnston. 2005. Forecasting exurban development to evaluate the influence of land-use policies on wildland and farmland conservation. Journal of Conservation Planning 1:40-57.

Milestad, R., and S. Hadatsch. 2003. Organic farming and social-ecological resilience: the alpine valleys of Sölktäler, Austria. Conservation Ecology 8(1):3.

Nowak, M. A. 2006. Five rules for the evolution of cooperation. Science 314(5805):1560-1563. http://dx.doi.org $\underline{110.1126 / \text { science. } 1133755}$

Ohmart, C., and S. Matthiasson. 2000. The Lodi Winegrower's Workbook: A self-assessment of integrated farming practices. Lodi-Woodbridge Winegrape Commission, Lodi, California, USA.

Ostrom, E. 1990. Governing the commons. Cambridge University Press, New York, New York, USA.

Ostrom, E. 2009. A general framework for analyzing sustainability of social-ecological systems. Science 325 (5939):419-422. http://dx.doi.org/10.1126/science.1172133

Pannell, D. J. 2008. Public benefits, private benefits, and policy intervention for land-use change for environmental benefits. Land Economics 84(2):225-240.

Prokopy, L. S., K. Floress, D. Klotthor-Weinkauf, and A. Baumgart-Getz. 2008. Determinants of agricultural best management practice adoption: evidence from the literature. Journal of Soil and Water Conservation 63(5):300-311. http:/ /dx.doi.org/10.2489/63.5.300

Reganold, J. P., D. Jackson-Smith, S. S. Batie, R. R. Harwood, J. L. Kornegay, D. Bucks, C. B. Flora, J. C. Hanson, W. A. Jury, D. Meyer, A. Schumacher, H. Sehmsdorf, C. Shennan, L. A. Thrupp, and P. Willis. 2011. Transforming U.S. agriculture. Science 332(6030):670-671. http://dx.doi.org/10. $\underline{1126 / \text { science. } 1202462}$

Robertson, G. P., and S. M. Swinton. 2005. Reconciling agricultural productivity and environmental integrity: a grand challenge for agriculture. Frontiers in Ecology and the Environment 3:38-46. http://dx.doi.org/10.1890/1540-9295(2005) 003[0038:RAPAEI]2.0.CO;2

Rogers, E. 2003. Diffusion of innovations. Fifth Edition. Free Press, New York, New York, USA.

Schnepf, M., and C. A. Cox. 2007. Environmental benefits of conservation on cropland: the status of our knowledge. Soil and Water Conservation Society, Ankeny, Iowa, USA.
Shaw, L., M. Lubell, and C. Ohmart. 2011. The evolution of local partnerships for sustainable agriculture. Society and Natural Resources 24(10):1078-1095. http://dx.doi.org/10.10 $\underline{80 / 08941920.2010 .550384}$

Spielmann, K. A., M. Nelson, S. Ingram, and M. A. Peeples. 2011. Sustainable small-scale agriculture in semi-arid environments. Ecology and Society 16 (1): 26. [online] URL: http://www.ecologyandsociety.org/vol16/iss1/art26/

Tornatzky, L. G., and K. J. Klein. 1982. Innovation characteristics and innovation adoption-implementation: a meta-analysis of findings. IEEE Transactions on Engineering Management 29(1):28-45.

Tourte L., R. Smith, L. J. Bettiga, T. Bensen, J. Smith, and D. Salm. 2008. Post-emergence herbicides are cost effective for vineyard floor management on the Central Coast. California Agriculture 62(1):19-23. http://dx.doi.org/10.3733/ca.v062n01p19

United States Department of Agriculture (USDA). $2009 a$. California grape acreage report summary. United States Department of Agriculture, National Agricultural Statistics Service, Washington, D.C., USA.

United States Department of Agriculture (USDA). $2009 b$. California grape crush report overview. United States Department of Agriculture, National Agricultural Statistics Service, Washington, D.C., USA.

Warner, K. 2007a. Agroecology in action: extending alternative agriculture through social networks. MIT Press, Cambridge, Massachusetts, USA.

Warner, K. D. 2007b. The quality of sustainability: agroecological partnerships and the geographic branding of California winegrapes. Journal of Rural Studies 23:142-155. http://dx.doi.org/10.1016/j.jrurstud.2006.09.009

Wejnert, B. 2002. Integrating models of diffusion of innovations: a conceptual framework. Annual Review of Sociology 28:297-326. http://dx.doi.org/10.1146/annurev.soc .28 .110601 .141051

${ }^{[1]}$ Because of space limitations on the survey, we did not ask respondents to evaluate the social or community benefits of each practice and did not include practices specifically designed to improve social welfare. The economic and environmental aspects of sustainability have historically been the initial focus of these programs, but social benefits such as farm worker health are receiving increasing emphasis. Other results from this study will partially address the social aspect. 